\title{
A Study on HRM Practices in Public Sector Banks in Krishnagiri District
}

\author{
*Dr.B.Mathivanan \\ Prof.\&Head, Department of Commerce, MGR College, Dr.MGR Nagar, Hosur-635 109.
}

\begin{abstract}
This article enlightened the banking activity which thrives on the strength of people power". People are the direct factors of productivity of its services and people are its sole consumers".

Banking was a thriving industry in ancient India. Initially, the industrial houses pioneered banks with a view to generating funds for productive activities and at the same time offered considerable security, liquidity and fair returns to the depositors. In a way, banking continued to be a traditional industry till 1969. When major banks were taken over by the Government of India. With nationalization, banks ceased to be funding agencies only for industrial sector and became a vivacious instrument of social change more statistical data are available in support of the preposition that there is a phenomenal growth of banking industry.
\end{abstract}

\section{Introduction}

Banking industry viewed from personnel angle has its peculiarities. It is a labour intensive industry and efficiency of employees has got a bearing on the quality of services offered. This being the case, it should have been natural that professionalization of personnel management should have gained better priority but unfortunately personnel management should have gained better priority but unfortunately personnel happened to be the most neglected aspect of banks management. The typical working of banks as such does not require any professional training not require any professional training and here is an industry where it is strongly believed that every one can do anything and as one know's no body does much to the prosperity of the organization. This aspect is further accentuated by the fact that banks operate in a seller's market with total absence of an element of competition and the prices of deposits accepted is determined by the banks, but by an external agency like the RBI and the GOI. In a sheltered environment like this, the need for professionalisation of bank management was never felt personnel happened to be managed by a non-expert and usually by a medicore officer who could not otherwise prosper on banking operations. With the implementation of recommendations of Pillai Committee a controversy was ranging among bankers whether or not Personnel Management is a specialized function. In the absence of scientific personnel practices being developed in the banking industry, a discontent workforce emerged which strengthened the trade union movement in banking industry.

\subsection{HRM in Banks}

The HRM practices in banks is gradually forging ahead. A majority of the banks have set up separate HRD Departments (HRDDs) within a decade of functioning, HRDDS in some banks have gained certain creditable achievements. The blanket criticism of the existing HRM functions as " Ornamental Appendages cannot be justified. However, it is true that functioning in a majority of the banks is far from satisfactory. There are also cases of banks where the HRDD discharges personnel administrative functions of recruitment, placement, transfer, promotion and training. The functioning of the HRDD in certain other banks show a transition towards HRD functions. In these banks, along with training, certain other activities like manpower planning and performance appraisal have been introduced yet, a few other banks have made rapid strides as far as the introduction of new HRM activities and sub-systems, such as systematic induction, quality circles, staff meetings are concerned besides introducing these systems, some banks have also taken appreciable efforts in perfecting certain system like training and performance appraisal, Nevertheless, there is a widespread feeling in the banking industry that there are no sufficient pay offs from the HRM functions and the system at the operational level are relegated to the level of rituals. The linkages between HRD systems and other related such systems in HRM are also not apparent.

\subsection{Objectives of Human Resource Management}

According to the Indian Institute of Personnel Management, "Personnel Management aims to achieve both efficiency and justice neither of which can be pursued successfully without the other. It seeks to bring together and develop into an effective organization the men and women who make up an enterprise, enabling each to make up an enterprise, enabling each to make his or her own best contribution to its success both as an individual and as a member of a working group. It seeks to provide fair terms and conditions of employment and satisfying work for those employed". 
The general objective of personnel (or) human resource management is to contribute towards the realization of the organizational goals. The specific objectives of personnel management may be listed as follows:

a. To achieve and maintain good human relationships within the organization.

b. To enable each person to make his maximum personal contribution to the effective working of the organization.

c. To ensure respect for human personality and the well-being of each individual.

d. To ensure maximum individual development of personnel.

e. To ensure satisfaction of various needs of individuals for achieving their maximum contribution towards organizational goals.

\subsection{Statement of the Problem}

Banking is now a part of the larger financial service industry. The number of players in the market and the range of services and facilities offered are increasing, thereby signifying more intense competition. The new economic environment has posed new challenges and opportunities for the banks. In contrast to the largely service based competition that banks have witnessed hitherto, the competition is now manifesting itself in the form of technology based competition and price based competition as well. The advent of new technologically well-equipped, structurally lean and capital strong banks is going to make a difference in the markets in terms of the range and the cost of services offered as also the speed and efficiency with which customer expectations are met. To survive in an intensely competitive market, banks must measure up in terms of efficiency. Market related as well as internal and one crucial factor that makes a big difference to competitive efficiency for any bank is the human resource factor.

It is against this backdrop that whole lot of HRM initiatives have to be taken by Indian Banks. Banks have to tone up their employees knowledge and skills. Attitudes have to be changed to equip them to meet the increasing client expectations. Realizing the importance of customer oriented corporate culture ad continuous up gradation of skill of their manpower in ensuring growth and maintaining its pre-eminent position, the banks heralded in redesigning the HRM area. It is a considerable study had yet to be made on the HRM aspects of banks as only in the last decade, several HRM systems have been evolved and experimented. This is an area in which banking industry needs considerable change in the basic premises for human resource management and development. Hence, the present study entitled " A Study on HRM Practices in Public Sector Banks in Krishnagiri District", has been undertaken. The area covered is Krishnagiri district only and the study is restricted to the public sector banks.

\subsection{Significance of the Study}

The HRM is a growing concept. It has tremendous relevance to service sector like banking. Human input is the single largest input that goes in the banking industry. The level of efficiency/production of this input gets reflected in the quality of service offered by banks to its customers, as also in its ultimate growth, productivity and profitability. Hence, the banks today lay great stress on HRM functions.

\subsection{Scope of the Study}

There are very few empirical studies on Human Resource Management and whatever sporadic researcher have been conducted, they tend to be survey researcher dwelling at length, the perceptions of employees and are undertaken mostly by Human Resource Management staff of those companies very few researchers outside the corporate management have attempted to study the Human Resource Management variables .

Unlike the previous studies, the present is empirical study and hence, the focus is on the hither to neglected Human Resources Management variables in the earlier, studies, viz., Performance Appraisal system, Training system, Recruitment Process, Quality circles. Human Resources information systems and impact a focus on Human Resources Management, by an independent and outside management researcher and hence, devoid of any bias.

\section{Objectives Of The Study}

1. To study the multivarious functions of HRM's and their relevance in achieving the targeted bank objectives.

2. To list out the prevailing HRM Mechanisms/tasks/assess how well HRM tasks are performed in public sector banks.

3. To study about the motivation factors influence the employee in public sector banks.

4. To study about the effectiveness of training system as well as performance appraisal system as followed in public sector banks. 
5. Based on the findings, to offer suggestions for improvements in the HRM system as applicable to public sector banks.

\section{Methodology}

There are 21 public sector banks presently functioning in India. The study embraces in its fold all the public sector banks in Krishnagiri District. The sample units thus account for roughly taken 150 employees working in the public sector banks.

The Independent-Samples $t$ test procedure is used to compares mean scores of opinion on level of motivation for the two groups of sex. The procedure assumes that the variances of the two groups are equal and it was tested with Levene's test statistics.

The Friedman test is a nonparametric alternative to the repeated measures analysis of variance. The Friedman test is the nonparametric equivalent of a one-sample repeated measures design or a two-way analysis of variance with one observation per cell.

The data collected for the present study are primary as well as secondary in nature. For analyzing and compiling the data the following sophisticated statistical tools are used apart from the use of simple tools like averages and percentages.

1. Chi-square Test

2. Ranking Techniques

3. Independent Samples t Test

4. Post Hoc Tests - Homogeneous Subsets

5. ANNOVA Table

6. Friedman Test

The above tests are used to identify the opinion level of the bank employees in the public sector banks in the Krishnagiri District.

\subsection{Framework of Analysis}

The perspectives of the HRM systems adopted by public sector banks in India, particularly in Krishnagiri District is examined from data collected from published and unpublished sources such as Books, Journals, Various study groups, Special enactments, Reserve Bank of India Bulletins, Annual reports and Reports published by the Government of India. The primary data is collected through the questionnaire method.

\subsection{Hypotheses}

a) There is no association between age and level of satisfaction on over all services.

b) There is no association between sex and level of satisfaction on over all services.

c) There is no association between education and level of satisfaction on over all services.

d) There is no association between income and level of satisfaction on over all services

\subsection{Limitations of the study}

1. As the variable involved in human being, the conclusions are subjective and cannot be taken as universally applicable. Moreover, the findings depend on people who have answered the questions and are subject to their personal prejudices an whimsical fancies.

2. The delimitations of the questionnaire are equally applicable to the present study as well.

3. The sample size is roughly $10 \%$ of the public sector banks in Krishnagiri district. The time and cost constraints have prevented the researcher in taking sample on a large scale.

\section{Literature Review}

1. "Management of Human Assets" by M.G.Rao, a compendium, threw light on the complexities of Managing human beings in the present day organizations. The various aspects of HRM in relation to small scale units operating in industrial estates have been presented initially, followed by theoretical presentation on HRD, different aspects of training, organizational development, employee participation, etc. The effects of training and employee developmental activities have also been put to close examination. It also been put to find how the employee related activities flourish in various other sectors like urban government, cooperatives, informal sector and small sector.

2. "HRM 2000" by P.Subbarao, a compendium, presented the various developments in the HRM in a comprehensive form. It is also attempted to look into the current trends in Human Resource Function with a view to outline the future development that are likely to take place in the years ahead. It also discussed in a lucid manner the topics such as job analysis, job evaluation, employee benefits, recruitment and selection, line staff conflicts, social responsibility policies along with other current topics such as organizational 
culture and climate, organizational politics, organizational effectiveness, follower ship, participative management, dual career problems, quality of worklife, qualify circles and organizational development.

3. "Emerging Issues in Human Resources Management by Pramod Verma, a volume, attempted to present state-of-the-art explanations and experiences on the emerging issues in managing human resources in various organizations.

4. "Excellence through Human Resource Development" by M.R.R Nair and T.V.Rao, an edited compendium, focused on chief executives views and experiences on HRD. It also dealt with the HRD Philosophy, importance, macro level issues, expectations of line managers and workers from HRD, role of HRD managers, dimensions of developing HRD facilitators and programmes.

5. "Management of Human Resources in Public Enterprises" edited by S.Ravishankar and R.K.Mishra provided an understanding of the system of HRM rather than merely the activities assigned to those who provided various personnel services for effective public enterprise management. It also gave a balanced and comprehensive grasp of the concept, problem, approaches and strategies of HRM.

6. Jayanthi Lal Jain, in his study entitled "An Empirical Model on Micro-Level Manpower Planning in Banks", presented an empirical model for micro-level manpower planning in banks and provided a framework required for evolving certain norms which have already been in vogue in the Indian Bank and have proved to be extremely useful in planning as well as allocating staff to various branches of the bank. It also suggested values of parameters/norms to be used in micro-level manpower planning and provided a frame work for assessing the viability of norms and gave guidelines for proper implementation of those norms.

7. "A Micro-Level Manpower Planning Model for Banks" by Jayanthi Lal Jain and K.Balachandran, was a modified version of the model suggested by the first author (previous reference) after incorporating the changing requirements of public sector banks for optimal distribution of manpower, of course without any change in the basic model.

8. "Leadership styles among Bank Managers" by O.P.Misra and S.K.Srivastava, a research study, studied the leadership style which is one of the objectives of HRD and its effectiveness among bank managers belonging to nationalized and private sector banks and relationships between styles and effectiveness among 45 sample managers selected from nationalized and private sector banks.

9. "Job Descriptions in a Public Sector Banks" by V.T.Godse and R.Bandyopadhyay, a research study, concerned with the conduct of job description exercise in one of the leading nationalized banks. It identified the problems faced by banks on account of expansion and diversification of business activities, suggested ways and means to handle the problems and portrayed clearly the procedure followed for job description exercise at various levels of management besides, highlighting the use of interval highlighting the use of interval appraisal in identifying structural deficiencies.

10. Uma Sekaran in his study entitled "The perceived quality of working life in banks in major cities in India", examined the QWL in the Indian Banking Industry as perceived by organizational members at different organizational levels and in different job positions, several variables such as competence, performance, involvement and satisfaction with various facets of the work life were taken into consideration for the purpose, since these are all indices of the QWL.

11. "Organisational Effectiveness in Banks" by Usha Sunderarajan determined the factors with contribute a) to organizational effectiveness and b) to differences, if any, in the effectiveness of public and private sector organizations. The study compared the various climate factors which tend to increase or diminish the effectiveness of organizations, taking into account two public sector banks and one private sector bank.

12. "Innovative practices followed by State Bank of India for educating and developing their employees" by K.Rajendra Prasad, a case and an exploratory study, dwelled upon few of creative and innovative efforts in SBI, Viz., Performance Appraisal, Quality Circles, Job Rotation, Training and Assessment, HRD Quiz, Self - Learning Centre actions, Messenger to Manager Programmes, Organisation Development Intervention exercises, etc., all of which are aimed at training and developing the bank's workforce.

13. R.Prakasam, in his study entitled "Job Rotation Practices in Banks and Employee Attitudes", empirically examined the present state of affairs in the banks in terms of the extent of job rotation practices and the major obstacles faced by them in implementing the same. It also studied the extent of job-rotation practices in the organization. The analysis was based on the data obtained from the NIBM'S employee opinion survey. This nation-wide survey collected from the opinions and reactions of about 7,000 bank employees representing the SBI and other fourteen major nationalized banks from all parts of the country, regarding the various personal policies of their respective banks.

14. "A study of motivation profile of SBI officers", by Prabhat Kumar and Rakesh Rastogi, identified the factors that will motivate officers to give their best performance(in terms of both quality and quantity) to the bank, the level of availability of these factors and main causes of frustration in the bank. 
15. “An empirical study of bank manager's functioning in rural Punjab” by Rajeev Kansal, identified various factors or characteristics such as political nterference, lack of confidence in the banking staff, disinterestedness to maintain cost-effectiveness, lack of confidence, impact of trade unionism, proper decentralization of power at the lower level, lack of impartiality, fairness and security, which make a bank manager effective.

\section{Analysis And Discussion}

\subsection{ASSOCIATION BETWEEN PERSONAL PROFILE FACTORS AND LEVEL OF SATISFACTION ON OVER ALL SERVICES}

The association between the personal profile factors namely Age, sex, education, monthly income, occupation, and employee satisfaction with service provided by public sector banks was analyzed in this section. The chi square test is used at $5 \%$ level of significance.

\section{1.a Association between Level of satisfaction on over all services and Age}

The association between Age and level of satisfaction on over all services is analyzed and the results were given in the following bivariate Table 1

Null Hypothesis: $H_{0}$ : There is no association between Age and Level of satisfaction on over all services

Table 1 Age * Level of satisfaction on over all services

\begin{tabular}{|c|c|c|c|c|c|c|}
\hline \multicolumn{2}{|c|}{ Particulars } & \multicolumn{4}{|c|}{ Level of satisfaction on over all services } & \multirow[t]{2}{*}{ Total } \\
\hline & & Disagree & Undecided & Agree & Strongly agree & \\
\hline \multirow[t]{8}{*}{$\overline{\mathrm{Age}}$} & Below 25 & 2 & 4 & 5 & 2 & 13 \\
\hline & & $1.3 \%$ & $2.7 \%$ & $3.3 \%$ & $1.3 \%$ & $8.7 \%$ \\
\hline & $25-35$ & 5 & 9 & 19 & 5 & 38 \\
\hline & & $3.3 \%$ & $6.0 \%$ & $12.7 \%$ & $3.3 \%$ & $25.3 \%$ \\
\hline & $35-45$ & 5 & 17 & 20 & 11 & 53 \\
\hline & & $3.3 \%$ & $11.3 \%$ & $13.3 \%$ & $7.3 \%$ & $35.3 \%$ \\
\hline & $45-60$ & 3 & 9 & 20 & 14 & 46 \\
\hline & & $2.0 \%$ & $6.0 \%$ & $13.3 \%$ & $9.3 \%$ & $30.7 \%$ \\
\hline \multirow{2}{*}{\multicolumn{2}{|c|}{ Total }} & 15 & 39 & 64 & 32 & 150 \\
\hline & & $10.0 \%$ & $26.0 \%$ & $42.7 \%$ & $21.3 \%$ & $100.0 \%$ \\
\hline
\end{tabular}

In order to find the relationship between the Age of the respondents and Level of satisfaction on over all services, a chi-square test was used and result of the test is shown in the following table 1.1

Table 1.1 Age * Level of satisfaction on over all services -Chi square Test

\begin{tabular}{|c|r|r|r|c|}
\hline Age & Value & df & P value & Remark \\
\hline Pearson Chi-Square & 7.049 & 9 & .632 & Not Significant \\
\hline
\end{tabular}

It is noted from the above table that the ' $p$; value is greater than 0.05 and hence the result is not significant at $5 \%$ level. Hence the hypothesis' Age of the respondents and the Level of satisfaction on over all services are not associated does hold well. From the analysis it is concluded that there is no close relationship between the Age of the respondents and Level of satisfaction on over all services.

\subsection{Association between Age and Level of motivation}

The association between age and level of motivation is analyzed and the results were given in the following bivariate Table 2

Null Hypothesis: $H_{0}$ : There is no association between Age and Level of motivation. 
Table 2

\begin{tabular}{|l|l|r|r|r|r|}
\hline \multicolumn{2}{|c|}{ Particulars } & \multicolumn{3}{c|}{ Level of Motivation } & Total \\
\hline & Low & Medium & High & \\
\hline Age & Below 25 & 0 & 8 & 5 & 13 \\
\hline & & $.0 \%$ & $5.3 \%$ & $3.3 \%$ & $8.7 \%$ \\
\hline & $25-35$ & 0 & 17 & 21 & 38 \\
\hline & & $.0 \%$ & $11.3 \%$ & $14.0 \%$ & $25.3 \%$ \\
\hline & $35-45$ & 1 & 24 & 28 & 53 \\
\hline & $45-60$ & $.7 \%$ & $16.0 \%$ & $18.7 \%$ & $35.3 \%$ \\
\hline & & $1.3 \%$ & $11.3 \%$ & $18.0 \%$ & $30.7 \%$ \\
\hline Total & & 3 & 66 & 81 & 150 \\
\hline & & $2.0 \%$ & $44.0 \%$ & $54.0 \%$ & $100.0 \%$ \\
\hline
\end{tabular}

Sources : Primary Data

In order to find the relationship between Age and Level of Motivation on over all services, a chi-square test was used and result of the test is shown in the following table 2.1

Table 2.1 Age * Level of Motivation

Chi-Square Tests

\begin{tabular}{|c|r|r|r|}
\hline Particulars & Value & df & P value \\
\hline Pearson Chi-Square & 4.537 & 6 & .604 \\
\hline
\end{tabular}

It is noted from the above table that the ' $p$; value is greater than 0.05 and hence the result is not significant at 5\% level. Hence the hypothesis' Age and the Level of motivation are not associated' does hold well. From the analysis it is concluded that there is no close relationship between the Age of the respondents and Level of motivation.

\subsection{Association between Education and Level of satisfaction on over all services.}

The association between Education and level of satisfaction on over all services is analyzed and the results were given in the following bivariate table 3.

Null Hypothesis: $H_{0}$ : There is no association between Education and Level of satisfaction on over all services.

Table 3 Education * Level of satisfaction on over all services

\begin{tabular}{|c|c|c|c|c|c|c|}
\hline \multicolumn{2}{|c|}{ Particulars } & \multicolumn{4}{|c|}{ Level of satisfaction on over all services } & \multirow[t]{2}{*}{ Total } \\
\hline & & Disagree & Undecided & Agree & Strongly agree & \\
\hline \multirow[t]{8}{*}{ Education } & $\overline{\mathrm{PG}}$ & 3 & 14 & 25 & 12 & 54 \\
\hline & & $2.0 \%$ & $9.3 \%$ & $16.7 \%$ & $8.0 \%$ & $36.0 \%$ \\
\hline & UG & 5 & 18 & 30 & 19 & 72 \\
\hline & & $3.3 \%$ & $12.0 \%$ & $20.0 \%$ & $12.7 \%$ & $48.0 \%$ \\
\hline & HSC & 6 & 5 & 7 & 1 & 19 \\
\hline & & $4.0 \%$ & $3.3 \%$ & $4.7 \%$ & $.7 \%$ & $12.7 \%$ \\
\hline & SSLC & 1 & 2 & 2 & 0 & 5 \\
\hline & & $.7 \%$ & $1.3 \%$ & $1.3 \%$ & $.0 \%$ & $3.3 \%$ \\
\hline \multirow{2}{*}{\multicolumn{2}{|c|}{ Total }} & 15 & 39 & 64 & 32 & 150 \\
\hline & & $10.0 \%$ & $26.0 \%$ & $42.7 \%$ & $21.3 \%$ & $100.0 \%$ \\
\hline
\end{tabular}

Sources : Primary Data

In order to find the relationship between Education and Level of Satisfaction on over all services, a chisquare test was used and result of the test is shown in the following table 3.1. 
Table 3.1 Education * Level of satisfaction on over all services Chi-Square Tests

\begin{tabular}{|c|r|r|r|}
\hline Particulars & Value & df & P value \\
\hline Pearson Chi-Square & 16.084 & 9 & .065 \\
\hline
\end{tabular}

It is noted from the above table that the 'p; value is greater than 0.05 and hence the result is not significant at $5 \%$ level. Hence the hypothesis' Education and the Level of Satisfaction of over all services are not associated' does hold well. From the analysis it is concluded that there is no close relationship between the Education and Level of Satisfaction of over all services

\subsection{Association between Income and Level of satisfaction on over all services.}

The association between Income and level of satisfaction on over all services is analyzed and the results were given in the following bivariate Table 4.

Null Hypothesis: $H_{0}$ : There is no association between Income and Level of satisfaction on over all services.

Table 4 Income * Level of satisfaction on over all services

\begin{tabular}{|c|c|c|c|c|c|c|}
\hline \multicolumn{2}{|c|}{ Particulars } & \multicolumn{4}{|c|}{ Level of satisfaction on over all services } & \multirow[t]{2}{*}{ Total } \\
\hline & & Disagree & Undecided & Agree & Strongly agree & \\
\hline \multirow[t]{6}{*}{ Income } & $5000-10000$ & 8 & 19 & 20 & 8 & $\overline{55}$ \\
\hline & & $5.3 \%$ & $12.7 \%$ & $13.3 \%$ & $5.3 \%$ & $36.7 \%$ \\
\hline & $10000-15000$ & 5 & 14 & 33 & 19 & 71 \\
\hline & & $3.3 \%$ & $9.3 \%$ & $22.0 \%$ & $12.7 \%$ & $47.3 \%$ \\
\hline & 15000 - Above & 2 & 6 & 11 & 5 & 24 \\
\hline & & $1.3 \%$ & $4.0 \%$ & $7.3 \%$ & $3.3 \%$ & $16.0 \%$ \\
\hline \multirow{2}{*}{\multicolumn{2}{|c|}{ Total }} & 15 & 39 & 64 & 32 & 150 \\
\hline & & $10.0 \%$ & $26.0 \%$ & $42.7 \%$ & $21.3 \%$ & $100.0 \%$ \\
\hline
\end{tabular}

Sources : Primary Data

In order to find the relationship between Income and Level of Satisfaction on over all services, a chisquare test was used and result of the test is shown in the following table 4.1

Table 4.1 Income * Level of satisfaction on over all services Chi-Square Tests

\begin{tabular}{|c|r|r|r|}
\hline Particulars & Value & df & P value \\
\hline Pearson Chi-Square & 7.437 & 6 & .282 \\
\hline
\end{tabular}

It is noted from the above table that the " $p$; value is greater than 0.05 and hence the result is not significant at 5\% level. Hence the hypothesis' Income and the Level of Satisfaction of over all services are not associated' does hold well. From the analys is it is concluded that there is no close relationship between the Income and Level of Satisfaction of over all services.

\subsection{ANOVA}

The test for mean score analysis (ANOVA) test procedure is used to compares mean scores of opinion on level of motivation for more than two groups. The procedure assumes that the variances of the groups are equal and it was tested with Levene's test statistics. The significant difference between the mean scores of opinion on level of motivation is tested with respect to the various personal profile factors like Age, occupation, name of the bank, educational qualification and income .

\subsection{Test for mean scores of opinion on level of motivation and age group of the respondents.}

Test for mean scores of opinion on level of motivation and age group of the respondents was tested wit ANOVA test procedures and the results of the analysis are given in Table 5. 
Null Hypothesis: $\mathbf{H}_{\mathbf{0}}$ : There is no significant difference between the mean scores of age groups regarding with opinion on level of motivation.

Table 5

ANOVA- level of motivation and age

\begin{tabular}{|c|c|c|c|c|c|c|}
\hline Age & $\mathbf{N}$ & Mean & Std. Deviation & Std. Error & $\mathbf{F}$ & Sig. \\
\hline Below 25 & 13 & 25.38 & 3.380 & .937 & \multirow{5}{*}{.329} & \multirow{5}{*}{.804} \\
\hline $25-35$ & 38 & 26.03 & 3.928 & .637 & & \\
\hline $35-45$ & 53 & 26.42 & 3.692 & .507 & & \\
\hline $45-60$ & 46 & 26.48 & 4.396 & .648 & & \\
\hline Total & 150 & 26.25 & 3.930 & .321 & & \\
\hline
\end{tabular}

Sources : Primary Data

The above table 5 displays the descriptive statistics of the sample size, mean, standard deviation and standard error. The table also shows that the F statistics, calculated as the ratio of the variances. The column $\mathrm{P}$ value shows the probability value from the $\mathrm{F}$ distribution. Since the $\mathrm{P}$ value is greater than 0.05 we accept the hypothesis. Hence there is no significant difference in the mean scores of the age groups with respect to the opinion on level of motivation.

\subsection{Test for mean scores of opinion on level of motivation and Education.}

Test for mean scores of opinion on level of motivation with respect to education was tested with ANOVA test procedures and the results of the analysis are given in Table 6.

Null Hypothesis: $\mathbf{H}_{\mathbf{0}}$ : There is no significant difference between the mean scores of education groups regarding with opinion on level of motivation.

Table 6

ANOVA- level of motivation and education

\begin{tabular}{|c|c|c|c|c|c|c|}
\hline Education & N & Mean & Std. Deviation & Std. Error & F & Sig. \\
\cline { 1 - 5 } PG & 54 & 27.43 & 3.927 & .534 & & \\
\cline { 1 - 5 } UG & 72 & 25.99 & 3.376 & .398 & \multirow{2}{*}{4.477} & \multirow{2}{*}{.005} \\
\cline { 1 - 5 } HSC & 19 & 24.95 & 4.731 & 1.085 & & \\
\cline { 1 - 5 } SSLC & 5 & 22.20 & 4.438 & 1.985 & & \\
\cline { 1 - 5 } Total & 150 & 26.25 & 3.930 & .321 & & \\
\hline
\end{tabular}

Sources : Primary Data

The above table 6 displays the descriptive statistics of the sample size, mean, standard deviation and standard error. The table also shows that the F statistics, calculated as the ratio of the variances. The column $\mathrm{P}$ value shows the probability value from the F distribution. Since the P value is less than 0.05 we reject the hypothesis. Hence there is significant difference in the mean scores of the groups with respect to the opinion on level of motivation.

Table -7

Post Hoc Tests - Homogeneous Subsets - Level of Motivation - Tukey B

\begin{tabular}{|l|r|r|r|}
\hline \multirow{2}{*}{ Education } & \multirow{2}{*}{$\mathbf{N}$} & \multicolumn{2}{|c|}{ Subset for alpha = .05 } \\
\cline { 3 - 4 } & & \multicolumn{1}{|c|}{$\mathbf{1}$} & \multicolumn{1}{c|}{$\mathbf{2}$} \\
\hline SSLC & 5 & 22.20 & \\
\hline HSC & 19 & 24.95 & 24.95 \\
\hline UG & 72 & & 25.99 \\
\hline PG & 54 & & 27.43 \\
\hline
\end{tabular}

Once we have determined that differences exist among the means, post hoc range tests can determine which means differ. Tukey's tests identified the homogeneous subsets of means that are not different from each 
other. The table shows that the below graduate group do not differ significantly with other groups. But these groups significant differ with S.S.L.C and H.SC groups. There is significant difference between the U.G and the PG groups. Similarly there is no significant difference between S.S.L.C and H.SC groups.

\subsection{Independent-Samples T Test}

The Independent-Samples $t$ test procedure is used to compares mean scores of opinion on level of motivation for the two groups of sex. The procedure assumes that the variances of the two groups are equal and it was tested with Levene's test statistics. The results of the analysis are given in Table 8.

Null Hypothesis: $\mathbf{H}_{\mathbf{0}}$ : There is no significant difference between the mean scores of male and female regarding with opinion on level of motivation.

Table -8

T-Test Group Statistics

\begin{tabular}{|l|l|r|r|r|r|r|r|}
\hline \multicolumn{1}{|c|}{ Particulars } & \multicolumn{1}{|c|}{ Gender } & \multicolumn{1}{c|}{ N } & \multicolumn{1}{c|}{ Mean } & $\begin{array}{c}\text { Std. } \\
\text { Deviation }\end{array}$ & Std. Error Mean & t & P value \\
\hline Preference level & Male & 69 & 18.33 & 2.337 & .281 & \multirow{2}{*}{.418} & .677 \\
\hline & Female & 41 & 18.07 & 4.204 & .656 & & \\
\hline
\end{tabular}

Sources : Primary Data

The above table 8 displays the descriptive statistics of the sample size, mean, standard deviation and standard error. The table also shows that the t statistics, calculated as the ratio of the difference between sample means divided by the standard error of the difference. The column P value shows the probability value from the $\mathrm{t}$ distribution. Since the $\mathrm{P}$ value is greater than 0.05 we accept the hypothesis. Hence there is no significant difference in the mean scores of the two groups with respect to the opinion on level of motivation.

5.9 Test for mean scores of opinion on oneway level of motivation and Designation.

Test for mean scores of opinion on oneway level of motivation with respect to designation was tested with ANOVA test procedures and the results of the analysis are given in Table 9.

Null Hypothesis: $\mathbf{H}_{\mathbf{0}}$ : There is no significant difference between the mean scores of designation groups regarding with opinion on level of motivation.

Table - 9

Oneway Level of Motivation

\begin{tabular}{|c|c|c|c|c|c|c|}
\hline & $\mathrm{N}$ & Mean & Std. Deviation & Std. Error & $\mathrm{F}$ & Sig. \\
\hline Manager & 13 & 28.08 & 3.570 & .990 & \multirow{5}{*}{1.095} & \multirow{5}{*}{.353} \\
\hline Officer & 51 & 26.20 & 3.736 & .523 & & \\
\hline Clerical & 51 & 26.12 & 4.227 & .592 & & \\
\hline Sub-staff & 35 & 25.83 & 3.861 & .653 & & \\
\hline Total & 150 & 26.25 & 3.930 & .321 & & \\
\hline
\end{tabular}

Sources : Primary Data

The above table 9 displays the descriptive statistics of the sample size, mean, standard deviation and standard error. The table also shows that the t statistics, calculated as the ratio of the difference between sample means divided by the standard error of the difference. The column $\mathrm{P}$ value shows the probability value from the $\mathrm{t}$ distribution. Since the $\mathrm{P}$ value is greater than 0.05 we accept the hypothesis. Hence there is no significant difference in the mean scores of the two groups with respect to the opinion on level of motivation.

\subsection{Test for mean scores of opinion on oneway level of motivation and Name of the Bank.}

Test for mean scores of opinion on oneway level of motivation with respect to Name of the bank was tested with ANOVA test procedures and the results of the analysis are given in Table 10.

Null Hypothesis: $\mathbf{H}_{\mathbf{0}}$ : There is no significant difference between the mean scores of Name of the bank groups regarding with opinion on level of motivation.

Table - 10 -Oneway Level of Motivation

\begin{tabular}{|l|r|r|r|r|r|r|}
\hline & N & Mean & Std. Deviation & Std. Error & F & Sig. \\
\hline Union Bank of India & 12 & 26.83 & 2.552 & .737 & & \\
\cline { 1 - 5 } Canara Bank & 14 & 25.00 & 3.803 & 1.016 & \multirow{2}{*}{3.055} & .000 \\
\cline { 1 - 5 } Central Bank of India & 6 & 26.50 & 3.937 & 1.607 & & \\
\cline { 1 - 5 } State Bank of India & 33 & 27.15 & 3.734 & .650 & & \\
\hline
\end{tabular}




\begin{tabular}{|l|r|r|r|r|}
\hline Dena Bank & 5 & 22.40 & 3.435 & 1.536 \\
\hline Oriented Bank & 6 & 29.17 & 1.722 & .703 \\
\hline Cooperation Bank & 11 & 27.64 & 3.776 & 1.138 \\
\hline Indian Bank & 9 & 24.67 & 5.315 & 1.772 \\
\hline Indian Overseas Bank & 6 & 29.00 & 3.225 & 1.317 \\
\hline United Bank of India & 6 & 19.33 & 3.777 & 1.542 \\
\hline Punjab National Bank & 5 & 29.20 & 1.483 & .663 \\
\hline Bank of Baroda & 6 & 26.00 & 4.290 & 1.751 \\
\hline Vijaya Bank & 6 & 25.67 & 2.503 & 1.022 \\
\hline Syndicate Bank & 8 & 27.00 & 3.071 & 1.086 \\
\hline Allahabad Bank & 5 & 25.80 & 2.168 & .970 \\
\hline Andra Bank & 8 & 25.00 & 1.852 & .655 \\
\hline Bank of India & 4 & 26.50 & 5.916 & 2.958 \\
\hline Total & 150 & 26.25 & 3.930 & .321 \\
\hline
\end{tabular}

\section{Sources : Primary Data}

The above table 10 displays the descriptive statistics of the sample size, mean, standard deviation and standard error. The table also shows that the F statistics, calculated as the ratio of the variances. The column $\mathrm{P}$ value shows the probability value from the F distribution. Since the $\mathrm{P}$ value is less than 0.05 we reject the hypothesis. Hence there is significant difference in the mean scores of the groups with respect to the opinion on level of motivation.

Table -11

Post Hoc Tests - Homogeneous Subsets - Level of Motivation -Tukey B

\begin{tabular}{|l|r|r|c|c|}
\hline \multirow{2}{*}{ Name of the bank } & \multirow{2}{*}{$\mathbf{N}$} & \multicolumn{4}{|c|}{ Subset for alpha $=. \mathbf{0 5}$} \\
\cline { 3 - 5 } & & $\mathbf{1}$ & $\mathbf{2}$ & $\mathbf{3}$ \\
\hline United Bank of India & 6 & 19.33 & & \\
\hline Dena Bank & 5 & 22.40 & 22.40 & \\
\hline Indian Bank & 9 & 24.67 & 24.67 & 24.67 \\
\hline Canara Bank & 14 & 25.00 & 25.00 & 25.00 \\
\hline Andra Bank & 8 & 25.00 & 25.00 & 25.00 \\
\hline Vijaya Bank & 6 & & 25.67 & 25.67 \\
\hline Allahabad Bank & 5 & & 25.80 & 25.80 \\
\hline Bank of Baroda & 6 & & 26.00 & 26.00 \\
\hline Central Bank of India & 6 & & 26.50 & 26.50 \\
\hline Bank of India & 4 & & 26.50 & 26.50 \\
\hline Union Bank of India & 12 & & 26.83 & 26.83 \\
\hline Syndicate Bank & 8 & & 27.00 & 27.00 \\
\hline State Bank of India & 33 & & 27.15 & 27.15 \\
\hline Cooperation Bank & 11 & & 27.64 & 27.64 \\
\hline Indian Overseas Bank & 6 & & 29.00 & 29.00 \\
\hline Oriented Bank & 6 & & & 29.17 \\
\hline Punjab National Bank & 5 & & & 29.20 \\
\hline
\end{tabular}

Source : Primary Data

Once we have determined that differences exist among the means, post hoc range tests can determine which means differ. Tukey's tests identified the homogeneous subsets of means that are not different from each other. The table 11 shows that the group 1 do not differ significantly with other groups. But the groups 2 and 3 significant differ with 1 st group. There is significant difference between the group 1 and the group 2 . Similarly there is no significant difference between group 2 and group 3 except the banks United Bank of India,Oriental Bank and the Pubjab National Bank.

\subsection{Test for mean scores of opinion on oneway level of motivation and Income.}

Test for mean scores of opinion on oneway level of motivation with respect to Income was tested with ANOVA test procedures and the results of the analysis are given in Table 5.12. 
Null Hypothesis: $\mathbf{H}_{\mathbf{0}}$ : There is no significant difference between the mean scores of Income groups regarding with opinion on level of motivation.

Table - 12 -Oneway - Level of Motivation

\begin{tabular}{|l|r|r|r|r|r|r|}
\hline \multicolumn{1}{|c|}{ Income } & \multicolumn{1}{|c|}{$\mathbf{N}$} & Mean & Std. Deviation & Std. Error & F & Sig. \\
\hline $5000-10000$ & 55 & 26.00 & 4.096 & .552 & & \\
\cline { 1 - 5 } $10000-15000$ & 71 & 25.97 & 3.695 & .439 & 1.776 & .173 \\
\cline { 1 - 5 } 15000 - Above & 24 & 27.63 & 4.095 & .836 & & \\
\cline { 1 - 5 } Total & 150 & 26.25 & 3.930 & .321 & & \\
\hline
\end{tabular}

Sources : Primary Data

The above table 12 displays the descriptive statistics of the sample size, mean, standard deviation and standard error. The table also shows that the t statistics, calculated as the ratio of the difference between sample means divided by the standard error of the difference. The column $\mathrm{P}$ value shows the probability value from the $t$ distribution. Since the $P$ value is greater than 0.05 we accept the hypothesis. Hence there is no significant difference in the mean scores of the two groups with respect to the opinion on level of motivation.

\subsection{Test for mean scores of opinion on oneway level of motivation and Sex.}

Test for mean scores of opinion on oneway level of motivation with respect to Sex was tested with ANOVA test procedures and the results of the analysis are given in Table 13.

Null Hypothesis: $\mathbf{H}_{\mathbf{0}}$ : There is no significant difference between the mean scores of Sex groups regarding with opinion on level of motivation.

Table - 13 - T-Test

Group Statistics

\begin{tabular}{|c|c|c|c|c|c|c|c|}
\hline Particulars & Sex & N & Mean & Std. Deviation & Std. Error Mean & t & P value \\
\cline { 1 - 5 } Level of Motivation & Male & 100 & 26.13 & 3.789 & .379 & & \multirow{2}{*}{0.513} \\
\hline & Female & 50 & 26.48 & 4.229 & .598 & .609 \\
\hline
\end{tabular}

Sources : Primary Data

The above table 13 displays the descriptive statistics of the sample size, mean, standard deviation and standard error. The table also shows that the t statistics, calculated as the ratio of the difference between sample means divided by the standard error of the difference. The column $\mathrm{P}$ value shows the probability value from the $\mathrm{t}$ distribution. Since the $\mathrm{P}$ value is greater than 0.05 we accept the hypothesis. Hence there is no significant difference in the mean scores of the two groups with respect to the opinion on level of motivation.

\subsection{INFLUENCING FACTORS TOWARDS HRM IN PUBLIC SECTOR BANKS- Friedman Test}

The Friedman test is a nonparametric alternative to the repeated measures analysis of variance. The Friedman test is the nonparametric equivalent of a one-sample repeated measures design or a two-way analysis of variance with one observation per cell. Friedman tests the null hypothesis that k related variables come from the same population. For each case, the $\mathrm{k}$ variables are ranked from 1 to $\mathrm{k}$. The test statistic is based on these ranks. The Friedman test ranks the scores in each row of the data file independently of every other row. The HRM were classified in seven factors that factors influence the respondents. They are "Maximum extent,Present job,Future roles,High motivation,Subordinate relationship, Different teams and Promotion".

Table 14 Objectives of Human Resources Managment NPar Tests Descriptive Statistics

\begin{tabular}{|c|c|c|c|c|c|c|}
\hline Particulars & $\mathbf{N}$ & Mean & Std. Deviation & Mean Rank & Chi-square & $P$ value \\
\hline Maximum extent & 150 & 4.50 & 1.860 & 4.50 & \multirow{6}{*}{77.648} & \multirow{6}{*}{0.000} \\
\hline present job & 150 & 3.98 & 1.933 & 3.98 & & \\
\hline future roles & 150 & 3.47 & 2.110 & 3.46 & & \\
\hline High motivation & 150 & 3.41 & 1.932 & 3.40 & & \\
\hline Subordinate relationship & 150 & 3.33 & 1.793 & 3.31 & & \\
\hline Different teams & 150 & 4.43 & 1.866 & 4.42 & & \\
\hline
\end{tabular}




\begin{tabular}{|l|l|l|l|l|l|l|}
\hline Promote & 150 & 4.94 & 1.912 & 4.93 & & \\
\hline
\end{tabular}

Sources : Primary Data

To identify the factor which is more influencing the HRM in Public Sector banks for achieving the targeted bank objectives are in the Friedman's test analysis was used and the results were given in above Table 14. The factors influencing the objectives of the public sector banks are given in the mean rank in ascending order.

Table 15 Individual Development

NPar Tests - Descriptive Statistics

\begin{tabular}{|l|c|r|r|r|r|r|}
\hline \multicolumn{1}{|c|}{ Particulars } & N & Mean & Std. Deviation & Mean Rank & Chi-square & P value \\
\hline Promotion & 149 & 2.78 & 1.380 & 2.78 & & \\
\cline { 1 - 4 } Interest & 149 & 3.54 & 1.238 & 3.54 & & \\
\cline { 1 - 4 } Nomination & 149 & 3.40 & 1.493 & 3.40 & \multirow{2}{*}{44.913} & \multirow{2}{*}{0.000} \\
\cline { 1 - 5 } Personal & 149 & 2.65 & 1.409 & 2.65 & & \\
\cline { 1 - 4 } Organizational & 149 & 2.64 & 1.296 & 2.63 & & \\
\hline
\end{tabular}

Sources : Primary Data

To identify the factor which is more influencing the HRM in Public Sector banks for achieving the targeted bank Individual development are in the Friedman's test analysis was used and the results were given in above Table 15. The factors influencing the Individual development are given in the mean rank in ascending order.

Table 16 Organizational Development

NPar Tests - Descriptive Statistics

\begin{tabular}{|c|c|c|c|c|c|c|}
\hline Particulars & $\mathbf{N}$ & Mean & Std. Deviation & Mean Rank & Chi-square & $P$ value \\
\hline Performance & 148 & 5.11 & 2.151 & 5.11 & \multirow{8}{*}{85.854} & \multirow{8}{*}{0.000} \\
\hline Review & 148 & 5.27 & 2.101 & 5.26 & & \\
\hline Role analysis & 148 & 4.66 & 2.346 & 4.66 & & \\
\hline Rewards & 148 & 3.76 & 2.269 & 3.76 & & \\
\hline Potential & 148 & 4.40 & 2.421 & 4.40 & & \\
\hline Training & 148 & 3.40 & 2.089 & 3.40 & & \\
\hline Job rotation & 148 & 4.14 & 2.079 & 4.14 & & \\
\hline Job enrichment] & 148 & 5.28 & 2.099 & 5.28 & & \\
\hline
\end{tabular}

Sources : Primary Data

To identify the factor which is more influencing the HRM in Public Sector banks for achieving the targeted organizational development are in the Friedman's test analysis was used and the results were given in above Table 16. The factors influencing the organizational development are given in the mean rank in ascending order.

Table 17 Other Factors

NPar Tests- Descriptive Statistics

\begin{tabular}{|l|c|r|r|r|r|r|}
\hline \multicolumn{1}{|c|}{ Particulars } & N & Mean & Std. Deviation & Mean Rank & Chi-square & P value \\
\hline HR department & 150 & 2.52 & 1.186 & 2.52 & & \\
\cline { 1 - 4 } communication & 150 & 2.07 & 1.208 & 2.07 & & \\
\cline { 1 - 5 } Team building & 150 & 3.32 & 1.481 & 3.32 & \multirow{2}{*}{108.7} & 0.000 \\
\cline { 1 - 5 } Role clarity & 150 & 3.52 & 1.219 & 3.52 & & \\
\hline Inter personal & 150 & 3.57 & 1.287 & 3.57 & & \\
\hline
\end{tabular}

Sources : Primary Data

To identify the factor which is more influencing the HRM in Public Sector banks for achieving the targeted other factors are in the Friedman's test analysis was used and the results were given in above Tab1e 17. The factors influencing the other factors are given in the mean rank in ascending order.

\section{Summary Of Findings And Suggestions}

Based on the data compiled from the published annual reports of the public sector banks for the study period as well as duly filed questionnaires from the officials thereof, the following findings emanating from the present research study have been deduced. 
1. The $40 \%$ of the respondents are developing for the future roles \& $34 \%$ of the respondents are maintaining high motivation level of employees and developing the individual to realise his potentials to the maximum extent. No Uniformity is found in the matter of ranking of the objectives of HRM.

2. The HRM instruments like PAS and potential development exercises contributing to Individual Development.

3. The past research studies and literature have clearly revealed that prime challenge for top management and HRM functionaries in banks today is to mould the beliefs and values of their employees in favour of HRM Policy and systems.

4. The unions in banks need to modify the traditional role at the work place and start focusing on development roles like a) Initiation of HRM b) Communication c) Education and Training d) Welfare of bank employees e) Role in family vocational guidance and f) research.

5. Computerisation may reduce employment possibilities although the ament's experiment of computerization has kept the employment in a particular operation.

\subsection{Suggestions}

Based on findings emerged from the analysis of the data collected through questionnaires and interacting with the management officials of the public sector banks, the following suggestions are offered to improve the HRM as prevalent in banks.

1. An awareness is to be created at all levels that HRM is everybody's business and systems for creating such awareness are to be developed.

2. Banks should establish a high power HRM Committee at the corporate level. Alternatives, the form and the scope of the Training Advisory Committee will meet atleast once in 3 months. HRM task force at various levels may also be set up to implement various HRM measures as are initiated and approved by the HRM Committee.

3. All efforts must be continuously mode by banks to develop an over all HRM culture and climate at all levels. It is very important that line managers and other functionaries take appraisals of employees as an important part of their portfolio and do not consider it to be the job of either personnel or HRM alone at the corporate level.

4. The HRM surveys should be carried out in the banks every 3 years and findings of these surveys should be interpreted and suitable HRM interventions should be made. The suggestions emerging from these surveys need to be examined and followed up seriously.

5. Scope of employee suggestion schemes needs to be expanded to make it more participative and effective practical and useful suggestions should be encouraged.

6. Visiting faculty(with some behavioural science background) should be made to visit all the branches over a period of time, by giving advance notice to the branches and inviting questions and suggestions about the day-to-day problems. These could be discussed in a brainstorming session at the branches with a view to letting out pent up feelings if not for immediately solving them. This should be followed up suitable communication from controllers.

7. Tasks/assignments/paper presentation to individuals/group of participants should made as a regular feature experience sharing among participants to facilitate meaningful interaction should be provided for. To the extent feasible, structured and unstructured role plays in training sessions should be introduced.

8. Welfare measures particularly relation to hospitalization scheme, canteen facilities at branches, scholarships for children of staff holiday homes and library facilities at branches need reexamination and whenever feasible, these and other such welfare measures may be suitably modified for the benefit of staff.

9. More important personnal policies like transfer and promotion are to be viewed periodically transfer placement policy should be implemented in fairness with minimum adhocism and undue favouritism from either side. This will instill confidence amongst all.

10. The system of reward and punishment should be made more clear and transparent while there should be an institutionalized system for calling periodical information, good work done by staff for prompt appreciations of their deeds and punishment to the erring employees should be quick and proper to serve as a deterrent to others.

11. A thorough and scientific screening of the participants should be done before selecting employees for training so that the right type of personnel are selected for the right type of training.

12. The development oriented PAS should be integrated with the entire HRM system of the organization. The appraisal data should be used not only for promotion decisions but also identification of staff training needs, job placements, job enrichment and enlargement, talent spotting and career planning.

13. A basic commitment and a willingness on the part of the management and employees along with sustained planning efforts are required for the entry of computer in Indian banks. Bank managers should be prepared to mange the people so that right type of data can be used in the computer at the right time. Commitment of 
all the section of employees to computerization should be evolved to cover various sections of employees. The executives and administrators must make use of Computer Based Management Information System(CBMIS) to enhance the quality of their decisions.

14. New manual for computer audit should be prepared and the access to software, kind of access and the risks involved are required to be assessed periodically, so that of computerized branches serve the purpose of an audit and does not become a routine.

\section{Bibliography}

[1]. Agarwal R.D.(ed.) Bynamics of Personal Management in India, Tata Mc.Graw - Hill, New Delhi, 1977.

[2]. Agarwal S.L.Labour Relations in India, Macmillan, New Delhi, 2001.

[3]. Agarwal D.R.Labour Problems Social welfare and Security, Kitab Mahal, New Delhi,2000.

[4]. Agnihotri V., Industrial Relations in India, Atma Ram \& Sons, New Delhi, 1970.

[5]. Ahmad Abad, Management and Organization Development, Rachana Prakashan, New Delhi, 1972.

[6]. Balu. V. Human Resources Management Sri Venkateswara Publications Chennai 2002.

[7]. Barnard Chester, The functions of the Executive, Harward University Press, Cambridge, Mass, 1938.

[8]. Basil Douglus C., Leadership Skills for Executive Action American Management Association New York, 2006.

[9]. Bertram A., Colbert, The Management Information System in Management, Mc.Graw - Hill, New York, 2001 ,p.554

[10]. Bolar, Multi Performance Appraisal, Vikas Publishing House, New Delhi, 1979.

[11]. Brown J.A.C., The Social Psychology of Industry Penguin Books Ltd., Harmondsworth, 2001.

[12]. Basha M.M.A., " Training Techniques in varying cultures : American methods for India", Integrated Management, 1971.

[13]. Belasco, James A., and trice, M.Harrison, The Assessment of change in Training and Therapy, New York, Mc-Graw Hill, 1969.

[14]. Bhatmagr, R.G., from Quality Circles to Kaizen Relevance of Japanese Management Practices to India Banking, SBI Monthly Review, Aug 2006.

[15]. Chatterjee, T.N. Principles and Practice of Management Dhanpet Raj \& Sons, New Delhi, 1988.

[16]. Chhabra, T.N. Principles and Practice of Management Dhanpet Raj \& Sons, New Delhi, 2002.

[17]. Chhabra, T.N., and Suri, R.K. Industrial Relations, Dhanpat Rai \& Co., Delhi, 2000.

[18]. Chopra Rakesh. K. Management of Human Resources Text \& Cases, Kitab Matial, Allahabad, 2001.

[19]. Dale, Ernest, Management : Theory and Practice, Mc Graw-Hill Publishing Co., New Delhi, 2005.

[20]. Davis, Keith Human Behaviour at Work, Mc Graw-Hill Publishing Co., New Delhi, 2001.

[21]. Davis, Ralph, C., The fundamentals of Top Management Harper \& Brothers, New York, 1951.

[22]. Daysl L., and Adhikai K. Organisation and Administration Progressive Corporation, Bombay, 2003.

\section{RBI Websites}

FAQS : www.faqs.rbi.org.in

Committee reports : $\underline{w w w . r e p o r t s . r b i . o r g . i n}$

FII List : www.fiilist.rbi.org.in

Facilities for non residential Indians : www.nri.rbi.org.in

NBFC Notifications : www.nbfc.rbi.org.in

Master Circulars : www.mastercirculars.rbi.org.in

List of Svit filed accounts : www.defaulters.rbi.org.in

Currency Museum : www.museum.rbi.org.in

RBI Bulletin : www.bulletin.rbi.org.in

RBI Notifications : www.notifics.rbi.org.in

RBI Speeches : www.speeches.rbi.org.in

Weekly Statistical Supplement : www.wss.rbi.org.in

RBI Press Release : www.pr.rbi.org.in

RBI Annual Report : www.annualreport.rbi.org.in

www.rbi.org.in. 